\title{
PERAN TIM PENGAWALAN, PENGAMANAN PEMERINTAH DAN PEMBANGUNAN DAERAH (TP4D) KEJARI PALOPO DALAM PENCEGAHAN TINDAK PIDANA KORUPSI
}

\author{
Moh. Rizal Mannaba \\ Mahasiswa Magister Hukum Universitas Muslim Indonesia, Makassar
}

\begin{abstract}
The purpose of this study was (1) to find out and analyze the effectiveness of the role of the escort team, government security and regional development (TP4D) at Palopo in preventing corruption, (2). Knowing and analyzing the factors that influence the implementation of the role of the Guardian Team, Government and Regional Development (TP4D) at Palopo in preventing corruption. The research conducted by the author is a type of descriptive research with a juridicalempirical approach is research that examines positive legal rules in order to get answers to existing problems by linking to facts or phenomena about the role of TP4D Palopo in preventing corruption. Research Results show that The implementation of Attorney Palopo's TP4D duties in the prevention of corruption has been carried out effectively, including: escorting and safeguarding the course of government and development through preventive efforts; provide legal assistance in each stage of the development program; coordinate with the Internal Government Supervisory Apparatus (APIP) to prevent irregularities; monitoring and evaluating the implementation of work and development programs;
\end{abstract}

Keywords : Corruption, TP4D, Attorney

\begin{abstract}
Abstrak
Tujuan dari penelitian ini untuk Mengetahui dan menganalisis efektivitas peran Tim Pengawalan, Pengamanan Pemerintah dan Pembangunan Daerah (TP4D) Kejari Palopo dalam pencegahan tindak pidana korupsi, (2). Mengetahui dan menganalisis faktor-faktor yang mempengaruhi pelaksanaan peran Tim Pengawalan, Pengamanan Pemerintah dan Pembangunan Daerah (TP4D) Kejari Palopo dalam pencegahan tindak pidana korupsi. Penelitian yang dilakukan Penulis merupakan tipe penelitian deskriptif dengan pendekatan yuridis-empiris adalah penelitian yang mengkaji aturan-aturan hukum positif guna mendapatkan jawaban atas permasalahan yang ada dengan mengkaitkan dengan fakta-fakta atau fenomena-fenomena tentang peran TP4D Kejari Palopo dalam pencegahan tindak pidana korupsi. Hasil Penelitian Pelaksanaan tugas TP4D Kejari Palopo dalam pencegahan tindak pidana korupsi telah terlaksana secara efektif, termasuk: melakukan pengawalan dan pengamanan jalannya pemerintahan dan pembangunan melalui upaya-upaya preventif; memberikan pendampingan hokum dalam setiap tahapan program pembangunan; melakukan koordinasi dengan Aparat Pengawasan Internal Pemerintah (APIP) untuk mencegah terjadinya penyimpangan; melakukan monitoring dan evaluasi pelaksanaan pekerjaan dan program pembangunan;
\end{abstract}

Kata Kunci : Korupsi, TP4D, Kejaksaan 


\section{PENDAHULUAN}

Bangsa Indonesia yang sedang giat dalam melaksanakan reformasi pembangunan sangat membutuhkan suatu kondisi yang dapat mendukung terciptanya tujuan pembangunan nasional yaitu masyarakat yang adil dan makmur berdasarkan Pancasila. Salah satu kondisi tersebut adalah penegakan supremasi hukum yang merupakan syarat mutlak bagi kelangsungan dan berhasilnya pelaksanaan pembangunan nasional sesuai dengan jiwa reformasi. Untuk mewujudkan hal tersebut perlu ditingkatkan usaha-usaha untuk memelihara ketertiban, keamanan, kedamaian dan kepastian hukum yang mampu mengayomi masyarakat Indonesia.

Pemerintah pusat melalui Depertemen Dalam Negeri meninjau kelangkapan administrasi serta melihat sisi potensi, kondisi wilayah dan letak geografis kotip palopo yang berada pada jalur trans sulawesi dan sebagai pusat pelayanan jasa perdangangan terhadap beberapa kabupaten yang meliputi kabupaten Luwu, Kabupaten Luwu Utara, Tana Toraja dan Kabupaten Wajo serta didukung sarana dan perasarana yang memadai, kotip Palopo kemudian ditingkatkan statusnya menjadi daerah otonom kota palopo pada tanggal 2 Juli 2002 berdasarkan Undang-undang Nomor 11 tahun 2002 tentang pembentukan daerah otonom kota palopo. yang sebelumnya hanya memiliki 4 wilayah kecamatan yang meliputi 19 Kelurahan dan 9 desa namun seiring dengan perkembangan dinamika kota palopo dalam segala bidang sehingga untuk mendekatkan pelayanan pemerintahan kepada masyarakat pada tahun 2006 wilayah kecamatan dimekarkan menjadi 9 kecamatan dan 48 Kelurahan, setelah menjadi kota palopo pembagunan begitu pesat sehingga pelaksanaan pembagunan di kota palopo tidak lepas dengan peran masyarakat dan pemerintah kota palopo serta aparat penegak hukum baik itu kejaksaan maupun kepolisian. Banyak hal yang membuat baik buruknya pembagunan tersebut yaitu bagaimana pemerintah kota palopo mempersiapkan birokrasi yang benar - benar siap dan mampun sebagai pejabat yang ditunjuk oleh Walikota Palopo untuk menjadi Kepala satuan kerja perangkat daerah (SKPD), Kuasa pengguna anggaran (KPA), Kuasa Pembuat Komitmen ( PPK ), serta peran Pelaksana kegiatan yang melaksanakan 
pekerjaan di Lingkungan Pemerintah kota palopo baik Pelaksana Lokal maupun pelaksana dari luar kota palopo, dan pengawasan Aparat penegak Hukum khususnya Kejaksaan Negeri Palopo dalam pelaksanaan pembagunan dan mencegah terjadinya tindak pidana korupsi baik itu pada saat perencanaan, pelelangan, pelaksanaan dan laporan, Pemerintah kota palopo memiliki 36 Kepala Satuan Kerja Perangkat Daerah (SKPD) dan PDAM dan Rumah Sakit Daerah Sawerigading yang setiap tahun Satuan Kerja Perangkat Daerah (SKPD) dan PDAM, Rumah Sakit Daerah Sawerigading memiliki kegiatan pembagunan baik itu fisik bagunan maupun non fisik dengan banyaknya pembagunan setiap tahunnya di kota palopo masih ada penyelanggara negara yang menyalahgunakan jabatannya dan pihak lain seperti keluarga, kroni dan para pengusaha sehingga merugikan keuangan negara/daerah. perkara tindak pidana korupsi dikota palopo telah mengerogoti pembagunan dikota palopo sebagaimana yang telah jadi sebagai berikut :

1.Penyimpangan bantuan dana beras miskin tahun 2009 yang mengakibatkan kerugian negara sebesar Rp. 270.445.500. $00 \quad$ ( dua ratus tujuh puluh juta empat ratus empar puluh lima ribu rupiah) yang menjadi terdakwa camat dan lurah terungkap pada 2011.

2.Penyalahgunaan Dana Alokasi Khusus kegiatan rehap sekolah serta kegiatan pengadaan alat sekolah tahun anggaran 2012 yang mengakibatkan kerugian negara sebesar Rp. 91.313.000,00 ( sembilan puluh satu juta tiga ratus tiga belas ribu rupiah ) yang menjadi terdakwa sekertaris Dinas Pendidikan sekaligus sebagai pejabat pembuat komitmen terungkap pada 2014.

3.Penyalahgunaan Dana kas daerah kota palopo tahun anggaran 2009/2010 yang mengakibatkan kerugian negara sebesar Rp. 8.480.750.000 ( delapan milyar empat ratus delapan puluh juta tujuh ratus lima puluh ribu rupiah ) yang menjadi terdakwa kepala daerah, kepala bendahara umum daerah terungkap pada tahun 2015. 
4. Pengadaan alat kesehatan tahun 2013 pada Rumah Sakit Daerah Sawerigading yang merugikan keuangan negara sebasar Rp. 8.000.000.000 ( delapan milyar rupiah ) yang sekarang ini masih tahap persidangan yang menjadi terdakwa Kuasa Pengguna Anggaran, Pejabat pembuat komitmen dan pelaksana kegiatan yang terungkap pada tahun 2015

Diversi merupakan pemberian kewenangan kepada aparat penegak hukum untuk mengambil tindakan-tindakan kebijaksanaan dalam menangani atau menyelesaikan masalah pelanggar anak dengan tidak mengambil jalan formal antara lain menghentikan atau tidak meneruskan/melepaskan dari proses peradilan pidana atau mengembalikan/menyerahkan kepada masyarakat dan bentuk-bentuk kegiatan pelayanan sosial lainnya. Penerapan Diversi dapat dilakukan disetiap tingkat pemeriksaan, baik itu dilakukan oleh Penyidik, Penuntut Umum maupun oleh Hakim Anak. Hal tersebut dilakukan untuk mengurangi dampak negatif keterlibatan anak dalam proses peradilan tersebut.

Sehubungan dengan uraian di atas, tampaknya sangat sesuai dengan upaya Kejaksaan membentuk Tim Pengawalan, Pengamanan Pemerintahan \& Pembangunan Daerah (disingkat TP4D) sebagai upaya pencegahan korupsi dan percepatan pembangunan khususnya di Kota Palopo. Tujuan dibentuknya TP4D, yakni: 1) hilangnya keragu-raguan kuasa pengguna anggaran (KPA), kuasa pengguna komitmen (PPK), dan pelaksana kegiatan dalam melaksanakan kegiatannya, 2) terserapnya anggaran dengan baik dan tepat waktu, dan 3) pembangunan kota Palopo berjalan dengan baik tanpa korupsi

Adapun permasalahan-permasalahan pokok yang akan dibahas untuk dikaji dalam sebagai berikut : (1). Bagaimanakah peran Tim Pengawalan, Pengamanan Pemerintah dan Pembangunan Daerah (TP4D) Kejari Palopo dalam pencegahan tindak pidana korupsi, (2). Faktor apakah yang mempengaruhi pelaksanaan peran Tim Pengawalan, Pengamanan Pemerintah dan Pembangunan Daerah (TP4D) Kejari Palopo dalam pencegahan tindak pidana korupsi. Alasan penulis yaitu : (1). Untuk Mengetahui dan menganalisis efektivitas peran Tim Pengawalan, Pengamanan Pemerintah dan Pembangunan Daerah (TP4D) Kejari 
Palopo dalam pencegahan tindak pidana korupsi, (2). Mengetahui dan menganalisis faktor-faktor yang mempengaruhi pelaksanaan peran Tim Pengawalan, Pengamanan Pemerintah dan Pembangunan Daerah (TP4D) Kejari Palopo dalam pencegahan tindak pidana korupsi.

Menurut Lawrence M. Friedman dalam Soleman B. Taneka (2002:37) seorang pakar hukum mengemukakan bahwa fungsi mencakup lebih dari tiga jenis. Adapun fungsi hukum yang dimaksudkan ialah antara lain meliputi: (1) memberikan pedoman/pengarahan pada warga masyarakat untuk berprilaku, (2) pengawasan/pengendalian sosial (social control), (3) penyelesaian sengketa (dispute settlement), dan (rekayasa sosial (social engineering). Dalam hubungan ini banyak pakar telah mengemukakan pendapatnya. Lawrence M. Friedman dalam Soleman B. Taneka (2002:37), mengemukakan fungsi hukum itu, meliputi:

a. Pengawasan/pengendalian sosial (social control)

Hukum sebagai sarana pengendali sosial, yang mencakup semua kekuatan yang menciptakan serta memelihara ikatan sosial, teori imperatif tentang fungsi hukum dengan banyak menghubungkan dengan hukum pidana. Dalam kaitan ini, hukum sebagai sarana pemaksa yang melindungi warga masyarakat dari ancaman maupun perbuatan yang membahayakan diri serta harta bendanya.

Pengendalian sosial (social control) dari hukum, pada dasarnya memaksa warga masyarakat agar berprilaku sesuai dengan hukum, dengan kata lain pengendalian sosial daripada hukum dapat bersifat preventif maupun represif. Preventif merupakan suatu usaha untuk mencegah perilaku yang menyimpang, sedangkan represif bertujuan untuk mengembalikan keserasian yang terganggu.

b. Penyelesaian sengketa (dispute settlement)

Hukum sebagai sarana penyelesaian sengketa (dispute settlement). Di dalam masyarakat berbagai persengketaan dapat terjadi, misalnya antara keluarga yang dapat meretakan hubungan keluarga, antara mereka dalam suatu urusan bersama (company), yang dapat membubarkan kerjasama. Sengketa juga dapat mengenai perkawinan atau waris, 
kontrak, tentang batas tanah, dan sebagainya. Adapun cara-cara penyelesaian sengketa dalam suatu masyarakat, ada yang diselesaikan melalui lembaga formal yang disebut dengan pengadilan, dan ada yang diselesaikan secara sendiri oleh orang- orang yang bersangkutan dengan mendapat bantuan dari orang yang ada disekitarnya. Hal ini bertujuan untuk mengukur sampai berapa jauh terjadi pelanggaran norma dan apa yang harus diwajibkan kepada pelanggar supaya yang telah dilanggar itu dapat diluruskan kembali.

c. Rekayasa sosial (social engineering, redistributive, atau innovation). Fungsi hukum sebagai alat rekayasa sosial ini juga sering disebut sebagai a tool of engineering yang pada prinsipnya merupakan fungsi hukum yang dapat diarahkan untuk merubah pola-pola tertentu dalam suatu masyarakat, baik dalam arti mengokohkan suatu kebiasaan menjadi sesuatu yang lebih diyakini dan lebih ditaati, maupun dalam bentuk perubahan lainnya.

Pengertian korupsi secara etimologis menurut Andi Hamzah (2005: 135), berasal dari bahasa latin yaitu: "corruptio" atau "corruptus" yang kemudian muncul dalam banyak bahasa Eropa seperti Inggris dan Perancis yaitu “corruption”, dalam bahasa Belanda "korruptie" yang selanjutnya muncul pula dalam perbendaharaan bahasa Indonesia: korupsi, yang dapat berarti suka disuap. Selanjutnya menurut Hermien Hadiati Koeswadji (2005: 32), korupsi berasal dari kata "corrupteia" yang berarti "bribery" yang berarti memberikan/menyerahkan kepada seseorang agar orang tadi berbuat untuk keuntungan pemberi, atau juga berarti seducation yang berarti sesuatu yang manarik untuk seseorang berbuat menyeleweng. Hal tersebut biasanya dikaitkan dengan kekuasaan yang pada umumnya berupa suap, penggelapan dan sejenisnya.

\section{METODE PENELITIAN}

Penelitian yang dilakukan Penulis merupakan tipe penelitian deskriptif dengan pendekatan yuridis-empiris adalah penelitian yang mengkaji aturan-aturan hukum positif guna mendapatkan jawaban atas permasalahan yang ada dengan 
mengkaitkan dengan fakta-fakta atau fenomena-fenomena tentang peran TP4D Kejari Palopo dalam pencegahan tindak pidana korupsi guna terpenuhinya prasyarat ilmiah karena hendak menganalisis dan mengetahui faktor-faktor yang mempengaruhi pelaksanaan peran TP4D Kejari Palopo dalam pencegahan tindak pidana korupsi. Penelitian ini dilakukan dengan pendekatan empiris, untuk mengkaji atau menganalisis data primer yang berupa dengan wawancara dengan informan untuk memperoleh keterangan yang lebih jelas terhadap keterangan atau fakta-fakta yang ditemukan di lapangan, yang mana informan tersebut antara lain : para Jaksa, Aparat Pemerintahan Kuasa Pengguna Anggara (KPA), Pejabat Pembuat Komitmen (PPK), Para Pengusaha yaitu Pelaksana Kegiatan (Kontraktor) dan Lembaga swadaya masyarakat (LSM) diperoleh secara langsung dari para informan dan responden melalui teknik wawancara dan pengedaran daftar pertanyaan (kuisioner). dengan berbagai aspek tentang peran TP4D Kejari Palopo dalam pencegahan tindak pidana korupsi, kemudian dihubungkan dengan data-data sekunder berupa studi-studi yang bersumber dari literatur dan referensi, peraturan perundang-undangan dan dokumen-dokumen, sehingga dapat ditelaah Peran Tim Pengawalan, Pengamanan Pemerintah dan Pembangunan Daerah (TP4D) Kejari Palopo dalam Pencegahan Tindak Pidana Korupsi.

Lokasi penelitian ini adalah Kejaksaan Negeri Palopo dan seluruh Wilayah Pemerintahan Kota Palopo dengan pertimbangan bahwa dari lokasi penelitian tersebut Penulis akan memperoleh data-data Peran Tim Pengawalan, Pengamanan Pemerintah dan Pembangunan Daerah (TP4D) Kejari Palopo dalam Pencegahan Tindak Pidana Korupsi.

Dalam penelitian ini terdapat 2 (dua) jenis data yang hendak dikumpulkan untuk dianalisis yakni : (1). Data primer, yakni data yang diperoleh secara langsung di lapangan dalam hal ini berupa hasil wawancara dengan informan untuk memperoleh keterangan yang lebih jelas terhadap keterangan atau faktafakta yang ditemukan di lapangan, yang mana informan tersebut antara lain : para Jaksa, Aparat Pemerintahan Kuasa Pengguna Anggara (KPA), Pejabat Pembuat Komitmen (PPK), Para Pengusaha yaitu Pelaksana Kegiatan (Kontraktor) dan 
Lembaga swadaya masyarakat (LSM), (2). Data sekunder, yakni data yang diperoleh dari studi-studi yang bersumber dari literatur dan referensi, peraturan perundang-undangan dan dokumen-dokumen.

Populasi adalah keseluruhan atau himpunan obyek dengan ciri yang sama. Populasi dapat berupa himpunan orang, benda (hidup maupun mati), kejadian, kasus-kasus, waktu atau tempat dengan sifat atau ciri yang sama. Populasi dalam penelitian ini adalah perundang-undangan, Penegak hukum khususnya para Jaksa, Aparat Pemerintahan Kuasa Pengguna Anggaran (KPA), Pejabat Pembuat Komitmen (PPK), Para Pengusaha yaitu Pelaksana Kegiatan, Lembaga swadaya masyarakat (LSM) dan tokoh masyarakat. Dengan demikian, jumlah sampel dalam penelitian ini sebanyak 50 responden dengan menggunakan teknik purposive sampling yaitu dilakukan secara sengaja dengan pertimbangan sampel yang terpilih dianggap mampu mewakili populasi yang ada teknik pengumpulan data yang digunakan dalam penelitian ini adalah : (1). Angket (kuesioner) yaitu Penelitian ini menggunakan angket tertutup dan angket terbuka sebagai penjabaran dari indikator variabel-variabel penelitian. Pada angket tertutup disisipkan alternatif jawaban sehingga responden memilih salah satu jawaban alternatif yang tersedia pada setiap pertanyaan. Sedangkan pada angket terbuka tidak disediakan alternatif jawaban agar responden berkesempatan memberikan tanggapan terhadap pertanyaan yang diajukan. (2). Wawancara dimaksudkan untuk mendapatkan beberapa data yang belum terungkap dalam angket. Teknik wawancara ini ditujukan kepada sampel yang telah ditetapkan dalam penelitian, yang telah dipersiapkan pedoman wawancara yang terstruktur mempermudah perolehan data yang diteliti, (3). Dokumentasi yaitu Pengumpulan data yang mengacu pada dokumen-dokumen hukum yang dianalisis secara empiris dan normatif berkaitan dengan tema penelitian. Hal ini dimaksudkan untuk mengkaji teori-teori hukum, yurisprudensi dan aspek-aspek hukum dalam sosial kemasyarakatan yang berkaitan dengan peran TP4D Kejari Palopo dalam pencegahan tindak pidana korupsi.

Sesuai dengan permasalahan yang ingin dijawab dan tujuan yang ingin dicapai dalam penelitian ini, maka data yang terkumpul berupa data primer dan 
data sekunder dianalisis secara kualitatif untuk selanjutnya dilakukan analisis dengan jalan mengkonstruksikan pernyataan yang terdapat dalam dokumen dan peraturan perundang-undangan yang berlaku. Penelitian ini mengacu pada peraturan perundang-undangan yang ada sebagai hukum positif yang kemudian Penulis bandingkan dengan penerapan hukumnya di wilayah hukum Palopo.

\section{PENERAPAN PERAN TIM PENGAWALAN PENGAMANAN PEMERNTAH DAN PEMBANGUNAN DAERAH (TP4D) KEJARI PALOPO DALAM PENCENGAHAN TINDAK PIDANA KORUPSI}

Kejaksaan merupakan institusi sentral dalam penegakan hukum yang dimiliki oleh semua negara yang menganut paham rule of law. Penerapan ini bersifat beranekaragam dengan memperhatikan posisi, tugas, fungsi dan kewenangan sesuai dengan sistem hukum yang dianut suatu negara. Dari berbagai peraturan dapat diketahui bahwa peran, tugas dan wewenang lembaga kejaksaan sangat luas dan menjangkau area hukum pidana, perdata dan tata usaha negara.

Jaksa menurut Pasal 1 ayat (1) Undang-undang Nomor 16 Tahun 2004 tentang Kejaksaan Republik Indonesia adalah "Pejabat fungsional yang diberi wewenang oleh undang-undang untuk bertindak sebagai penuntut umum dan pelaksana putusan pengadilan yang telah memperoleh kekuatan hukum tetap, serta wewenang lain berdasarkan undang-undang”.

Mencermati isi Pasal 1 ayat (1) Undang-undang No. 16 Tahun 2004 ini, maka jaksa mempunyai beberapa wewenang penting yaitu:

1. Sebagai penuntut umum

2. Sebagai pelaksana putusan pengadilan yang mempunyai kekuatan hukum tetap

3. Serta adanya wewenang penting yang dijabarkan lebih lanjut di dalam Pasal 30 undang-undang tersebut. Undang-undang Nomor 16 Tahun 2004 mengatur secara tegas bahwa Kejaksaan memiliki kemerdekaan dan kemandirian dalam melakukan kekuasaan Negara dalam bidang penuntutan. Kedudukan Kejaksaan sebagai suatu lembaga pemerintahan yang melakukan kekusaan negara di bidang penuntutan, bila dilihat dari 
sudutkedudukan mengandung makna bahwa Kejaksaan merupakan suatu lembaga yang berada di bawah kekuasaan eksekutif. Sementara itu, bila dilihat dari sisi kewenangan kejaksaan dalam melakukan penuntutan berarti Kejaksaan menjalankan kekuasaan yudikatif.

Sehubungan dengan makna kekuasaan Kejaksaan dalam melakukan kekuasaan Negara di bidang penuntutan secara merdeka. Kejaksaan dalam melaksanakan fungsi, tugas dan wewenangnya terlepas dari pengaruh kekuasaan pemerintah, dan pengaruh kekuasaan lainnya. Hal ini berarti bahwa negara akan menjamin Jaksa di dalam menjalankan profesinya tanpa intimidasi, gangguan, godaan, campur tangan yang tidak tepat atau pembeberan yang belum teruji kebenarannya, baik terhadap pertanggung jawaban perdata, pidana, maupun lainnya.

Kedudukan Kejaksaan dalam peradilan pidana bersifat menentukan karena merupakan jembatan yang menghubungkan tahap penyidikan dengan tahap pemeriksaan di sidang pengadilan. Berdasarkan doktrin hukum yang berlaku suatu asas bahwa Penuntut Umum mempunyai monopoli penuntutan, artinya setiap orang baru bisa diadili jika ada tuntutan pidana dari Penuntut Umum, yaitu lembaga kejaksaan karena hanya Penuntut Umum yang berwenang mengajukan seseorang tersangka pelaku tindak pidana ke muka sidang pengadilan.

Selanjutnya wewenang Jaksa dalam tindak pidana korupsi diatur dalam Pasal 30 Undang-Undang No. 16 Tahun 2004 tentang Kejaksaan Republik Indonesia menyatakan bahwa: "Salah satu tugas dan kewenangan Kejaksaan di bidang pidana adalah melakukan penyidikan terhadap tindak pidana tertentu berdasarkan undang-undang”.

Penjelasan Pasal tersebut menyatakan bahwa, kewenangan dalam ketentuan ini adalah kewenangan sebagaimana diatur dalam Undang-undang Nomor 31 tahun 1999 tentang Pemberantasan Tindak Pidana Korupsi sebagaimana telah diubah dengan Undang-undang Nomor 20 tahun 2001 jo. Undang-undang Nomor 30 Tahun 2002 tentang Komisi Pemberantasan Korupsi. Kewenangan Jaksa selaku penyidik tindak pidana korupsi dimaksudkan untuk menampung beberapa ketentuan Undang-undang tersebut. 
Rumusan mengenai kewenangan menyidik di dalam Undang-undang Pemberantasan Tindak Pidana Korupsi dan Undang-undang Kejaksaan Republik Indonesia tersebut menyebutkan bahwa penyidik untuk tindak pidana korupsi adalah Kejaksaan yang mempunyai hak privilege yakni hak khusus untuk dapat melakukan tindakan penyidikan terhadap Tindak Pidana Korupsi. Selanjutnya istilah penyidikan menurut Pasal 1 angka 2 KUHAP adalah serangkaian tindakan penyidik dalam hal dan menurut cara yang diatur dalam undang-undang ini untuk mencari serta mengumpulkan bukti yang dengan bukti itu membuat terang tentang tindak pidana yang terjadi dan guna menemukan tersangkanya.

Terhadap tindak pidana korupsi, sebelum lahirnya Undang-undang No. 31 Tahun 1999, penyidikan terhadap tindak pidana korupsi dilakukan oleh Kejaksaan, tetapi setelah lahirnya Undang-undang No. 31 Tahun 1999, yaitu Pasca Agustus 1999, penanganan terhadap tindak pidana korupsi memiliki berbagai pemahaman. Ada pandangan yang mengatakan bahwa pihak kepolisian yang berhak melakukan penyidikan terhadap tindak pidana korupsi, namun ada pandangan lain yang mengatakan dengan bertitik tolak dari ide bahwa materi tindak pidana korupsi sebagai bagian dari hukum pidana khusus (ius specia, ius singular/bijzonder strafrecht), sebenarnya Kejaksaan berhak melakukan penyidikan terhadap tindak pidana korupsi

Sehubungan dengan ketidakjelasan tersebut, muncullah argumen-argumen yang mendasari bahwa Kejaksaan berwenang menangani penyidikan tindak pidana korupsi, yaitu:

1. Bahwa ketentuan hukum pidana dapat dikategorikan menjadi hukum pidana umum (ius commune) dan hukum pidana khusus (ius special, ius singular/bijzonder strafrecht). Ketentuan hukum pidana umum dimaksudkan untuk berlaku secara umum, sedangkan yang dimaksud dengan ketentuan hukum pidana khusus diartikan sebagai ketentuan hukum pidana yang mengatur kekhususan subjek dan perbuatan yang khusus (bijzonder lijk feiten). Tindak pidana korupsi sebagai bagian dari tindak pidana khusus juga memiliki kekhususan dalam hukum acara. 
2. Berdasarkan Keppres Nomor 228 Tahun 1967 tanggal 2 Desember 1967 tentang Pembentukkan Tim Pemberantasan Korupsi yang menentukan bahwa ketua timnya adalah Jaksa Agung, sesuai dengan Pasal 5 yang berbunyi: "Ketua Tim Pemberantasan Korupsi adalah Jaksa Agung, yang dalam melakukan tugasnya bertanggung jawab kepada Presiden”. Sedangkan tugas dan fungsinya sebagai koordinator penyidik diatur dalam Pasal 3, yang berbunyi: "Tim Pemberantasan Korupsi mempunyai fungsi memimpin, mengordinir dan mengawasi semua alat-alat penegak hukum yang berwenang, baik sipil maupun Angkatan Bersenjata Republik Indonesia dalam melakukan penyelidikan, penyidikan dan penuntutan perkara-perkara korupsi, baik yang dilakukan oleh oknum sipil maupun Angkatan Bersenjata Republik Indonesia".

3. Berdasarkan ketentuan Pasal 284 ayat (2) yang berbunyi: "Dalam waktu 2 tahun setelah undang-undang ini diundangkan, maka terhadap semua perkara diberlakukan ketentuan undang-undang ini, dengan pengecualian untuk sementara mengenai ketentuan khusus acara pidana sebagaimana disebutkan pada undang-undang tertentu, sampai ada perubahan dan dinyatakan tidak berlaku lagi”.

Penjelasan dari Pasal 284 ini terdapat dalam Pasal 17 Peraturan Pemerintah Nomor 27 Tahun 1983 tentang Pelaksanaan KUHAP yang berbunyi: "Penyidikan menurut ketentuan khusus acara pidana sebagaimana tersebut pada undang-undang tertentu sebagaimana dimaksud dalam Pasal 284 ayat (2) KUHAP dilaksanakan oleh penyidik, jaksa dan pejabat penyidik yang berwenang lainnya berdasarkan peraturan perundang-undangan".

Ketentuan yang menyatakan bahwa jaksa dapat menyidik tindak pidana tertentu, terdapat dalam Pasal 32 huruf b Undang-undang No. 5 Tahun 1991, yang menyatakan bahwa: "Jaksa Agung mengordinasikan penanganan perkara pidana tertentu dengan instansi terkait berdasarkan 
undang-undang yang pelaksanaan koordinasinya ditetapkan oleh Presiden".

4. Instruksi Presiden Nomor 15 Tahun 1983 dan Keputusan Presiden Nomor 15 Tahun 1991 yang menyatakan bahwa dalam pedoman pelaksanaan pengawasan, para menteri/pemimpin lembaga pemerintah non departemen/pemimpin instansi lainnya setelah menerima laporan adanya suatu perbuatan tindak pidana, maka pemimpin melakukan pengaduan tindak pidana dengan menyerahkan kepada Kepala Kejaksaan Republik Indonesia dalam hal terdapat indikasi tindak pidana khusus yakni tindak pidana korupsi.

5. Ketentuan pasal 39 Undang-undang Nomor 31 Tahun 1999 yang menyatakan bahwa: "Jaksa Agung mengordinasikan dan mengendalikan penyelidikan, penyidikan dan penuntutan tindak pidana korupsi yang dilakukan bersama-sama oleh orang yang tunduk pada peradilan umum dan peradilan militer".

6. Keppres Nomor 86 Tahun 1999 tentang susunan Organisasi dan Tata Kerja Kejaksaan Republik Indonesia, dalam Pasal 16 menyebutkan bahwa: "Jaksa Agung Tindak Pidana Khusus adalah unsur pembantu pimpinan dalam melaksanakan sebagian tugas dan wewenang serta fungsi kejaksaan di bidang yustisial mengenai tindak pidana khusus yang bertanggung jawab langsung kepada jaksa agung”.

7. Undang-undang Kejaksaan Nomor 5 Tahun 1991 jo. Undang-undang Nomor 16 Tahun 2004. Di dalam Undang-undang Nomor 5 Tahun 1991 diatur tidak secara tegas mengenai kewenangan Kejaksaan dalam penyidikan tindak pidana korupsi. Namun demikian, terdapat ketentuan yang secara tidak langsung mengakui eksistensi kejaksaan untuk menyidik tindak pidana korupsi.

Pasal 29 menyatakan bahwa disamping tugas dan wewenang melakukan penyidikan dalam Undang-undang Kejaksaan, Kejaksaan dapat diserahi tugas dan wewenang lain yang berkaitan dengan KUHAP Pasal 284 ayat (2), Undang-undang No. 03 Tahun 1971 jo. Undang-undang 
Nomor 31 Tahun 1999 jo. Undang-undang Nomor 20 Tahun 2001 tentang Tindak Pidana Korupsi, dan Undang-undang lain.

Dalam berkembangnya Undang-undang Kejaksaan yang baru yakni Undang-undang Nomor 16 Tahun Tahun 2004 diatur secara jelas mengenai penyidikan yakni dalam Pasal 30 ayat (1) huruf d yang menyebutkan : "Dibidang pidana, kejaksaan mempunyai tugas dan wewenang melakukanpenyidikan terhadap tindak pidana tertentu berdasarkan undang-undang".

8. Undang-undang Nomor 31 Tahun 1999 tentang Pemberantasan Tindak Pidana Korupsi, dalam Pasal 33 dinyatakan bahwa :"Dalam hal tersangka meninggal dunia pada saat dilakukan penyidikan, sedangkan secara nyata telah ada kerugian keuangan negara, maka penyidik segera menyerahkan berkas perkara hasil penyidikan tersebut kepada Jaksa Pengacara Negara atau diserahkan kepada instansi yang dirugikan untuk dilakukan gugatan perdata terhadap ahli warisnya".

Ketentuan dalam Pasal 34 Undang-undang Nomor 31 Tahun 1999 tentang Pemberantasan Tindak Pidana Korupsi, juga menyatakan: "Dalam hal terdakwa meninggal dunia pada saat dilakukan pemeriksaan di sidang pengadilan, sedangkan secara nyata telah ada kerugian keuangan negara, maka penuntut umum segera menyerahkan salinan berkas berita acara sidang tersebut kepada Jaksa Pengacara Negara atau diserahkan kepada instansi yang dirugikan untuk dilakukan gugatan perdata terhadap ahli warisnya".

Kejaksaan sebagai salah satu lembaga yang berwenang dan bertugas untuk melakukan penerangan hukum dan penyuluhan hukum ke masyarakat sebagaimana yang tercantum di dalam Undang-Undang Nomor 16 Tahun 2004 tentang Kejaksaan Agung Republik Indonesia dalam Pasal 30 ayat (3) huruf a yang menyatakan "Dalam Bidang Ketertiban dan Ketentraman Umum, Kejaksaan terus menyelenggarakan kegiatan peningkatan kesadaran hukum masyarakat". Hal tersebut dapat menjadi instrumen Kejaksaan guna meningkatkan kesadaran masyarakat terhadap hukum terutama dalam hal pencegahan dan penanggulangan tindak pidana korupsi. 
Korupsi diakui sebagai musuh bersama bagi seluruh masyarakat Indonesia karena dampak nyata tindak pindana korupsi bukan hanya menimbulkan high cost economy yang berakibat pada penurunan daya saing terhadap pasar global, tetapi juga merugikan negara dan dalam jangka panjang menimbulkan kerusakan moral individu, keluarga, warga masyarakat dan bangsa Indonesia.

Upaya pemberantasan tindak pidana korupsi di Kota Palopo tidak dapat hanya dilakukan secara parsial tetapi juga dilakukan secara komperhensif. Untuk itu membutuhkan optimnalisasi kinerja dari aparat hukum, di samping peran serta seluruh elemen masyarakat, di dalam mengungkap segala bentuk tindak pidana korupsi yang terjadi, terutama melalui laporan disertai dengan bukti permulaan cukup.

Kejaksaan berwenang melakukan penyelidikan dan penyidikan tindak pidana korupsi berdasarkan Pasal 284 ayat 2 KUHAP jo Pasal 17 Peraturan Pemerintah Nomor 27 Tahun 1983 dan sekaligus berwenang dalam tahap penuntutan sebagai penuntut umum dalam tindak pidana korupsi. Selanjutnya dalam Pasal 17 Peraturan Pemerintah Nomor 27 Tahun 1983 disebutkan bahwa penyidikan menurut ketentuan khusus acara pidana sebagaimana tersebut pada undang-undang tertentu sebagaimana dimaksud dalam Pasal 284 ayat (2) KUHP yang dilaksanakan oleh Penyidik, Jaksa, dan Pejabat Penyidik berwenang berdasarkan perturan perundang-undangan.

Dalam melaksanakan tugas koordinasi dengan instansi yang berwenang melakukan pemberantasan terhadap tindak pidana korupsi, maka Kejaksaan berwenang:

1. Mengkoordinasikan penyelidikan, penyidikan, dan penuntutan tindak pidana korupsi

2. Menetapkan sistem pelaporan dalam kegiatan pemberantasan tindak pidana korupsi

3. Meminta informasi tentang kegiatan pemberantasan tindak pidana korupsi

4. Melaksanakan dengan pendapat atau pertemuan dengan instansi berwenang melakukan pemberantasan tindak pidana korupsi 
5. Meminta laporan instansi terkait mengenai pencegahan tindak pidana korupsi.

peran Tim Pengawalan, Pengamanan Pemerintah dan Pembangunan Daerah (TP4D) Kejari Palopo dalam pencegahan tindak pidana korupsi, maka berikut akan diuraikan pelaksanaan tugas TP4D Kota Palopo, yang meliputi: (1) Melakukan pengawalan dan pengamanan jalannya pemerintahan dan pembangunan melalui upaya-upaya preventif; (2) Memberikan pendampingan hukum dalam setiap tahapan program pembangunan dari awal sampai akhir; (3) Melakukan koordinasi dengan Aparat Pengawasan Interen Pemerintah untuk mencegah terjadinya penyimpangan; (4) Bersama-sama melakukan monitoring dan evaluasi pelaksanaan pekerjaan dan program pembangunan; dan (5) Melaksanakan penegakan hukum represif ketika ditemukan bukti permulaan yang cukup. Untuk lebih jelasnya akan diuraikan berikut ini.

1. Melakukan pengawalan dan pengamanan jalannya pemerintahan dan pembangunan melalui upaya-upaya preventif.

Program TP4D tersebut merupakan program yang sangat baik, karena program ini tidak mengutamakan hukum tetapi lebih mengutamakan preventif dan pembinaan. Jadi, tugas tim TP4D yakni, mengawal, mengawal, mengamankan dan mendukung keberhasilan jalannya pemerintahan dan pembangunan melalui upaya-upaya pencegahan/preventif dan persuasif. Upaya pencegahan atau preventif yang dilakukan oleh TP4D Kota Palopo dilakukan dengan cara sebagai berikut:

a. Memberikan penerangan hukum di lingkungan instansi pemerintah, BUMN, BUMD dan pihak lain terkait materi tentang perencanaan, pelelangan, pelaksanaan pekerjaan, pengawasan pelaksanaan pekerjaan, perijinan, pengadaan barang dan jasa, tertib administrasi dan tertib pengelolaan keuangan negara. TP4D dalam memberikan penerangan hukum di lingkungan instansi pemerintah, BUMN, BUMD dimaksudkan agar perencanan, pelelangan, pelaksanaan 
pekerjaan, pengawasan pelaksaaan pekerjaan, perizinan, pengadaan barang jasa, tertib administrasi dan tertib pengelolaan keuangan negara dapat dilaksanakan dengan baik sesuai peraturan perundangundangan yang berlaku.

b. Melakukan diskusi atau pembahasan bersama instansi pemerintah, BUMN, BUMD untuk mengidentifikasi permasalahan yang dihadapi dalam penyerapan anggaran dan pelaksanaan pembangunan.

TP4D dalam melakukan diskusi atau pembahasan bersama dengan instansi pemerintah, BUMN, BUMD dimaksudkan untuk mengidentifikasi adanya permasalahan yang dihadapi sehingga penyerapan anggaran dan pelaksanaan pembangunan khususnya di Kota Palopo dapat berlangsung dengan baik.

c. Memberikan penerangan dan penyuluhan hukum baik atas inisiatif TP4D maupun atas permintaan pihak-pihak yang memerlukan, yang tempatnya dan waktu pelaksanaannya ditetapkan berdasarkan kesepakatan dan sesuai kebutuhan.

TP4D dalam memberikan penerangan dan penyuluhan hukum baik atas inisiatif TP4D maupun atas permintaan pihak-pihak yang memerlukan, di mana tempat dan waktu pelaksanaannya ditetapkan berdasarkan kesepakatan dan sesuai dengan kebutuhan, sehingga pelaksanaannya dapat lebih efektif guna mencegah terjadinya tindak pidana korupsi di Kota Palopo.

d. TP4D dapat melibatkan instansi atau pihak lain yang memiliki kapasitas, kompetensi dan relevan dengan materi penerangan dan penyuluhan hukum yang akan disampaikan kepada instansi pemerintah, BUMN dan BUMD.

TP4D dalam melaksanakan tugasnya dapat melibatkan instansi atau pihak lain yang memiliki kapasitas, kompetensi dan relevan dengan materi penerangan dan penyuluhan hukum yang akan disampaikan kepada instansi pemerintah, BUMN dan BUMD, sehingga 
penyuluhan hukum tersebut dapat memberikan perubahan dan manfaat bagi pemerintah setempat. Dengan demikian, tindak pidana korupsi di Kota Palopo dapat segera ditanggulangi dan diminimalisir peningkatannya di masa akan datang.

2. Melakukan penerangan dan penyuluhan hukum dalam setiap tahapan program pembangunan dari awal sampai akhir Pendampingan hukum dalam setiap tahapan program pembangunan dari awal sampai akhir, dilakukan dengan cara sebagai berikut:

a. Pembahasan hukum dari sisi penerapan regulasi, peraturan perundang-undangan, mekanisme dan prosedur dengan pejabat pengelola anggaran atas permasalahan yang dihadapi dalam hal penyerapan anggaran. Tugas TP4D dalam pembahasan hukum dilakukan dengan membahas aspek-aspek yang terkait dengan penerapan regulasi, peraturan perundang-undangan, mekanisme dan prosedur dengan pejabat pengelola anggaran yang terkait dengan permasalahan yang dihadapi dalam hal penyerapan anggaran tersebut. Oleh karena itu, tugas TP4D tersebut harus dimaksimalkan agar dapat mencegah terjadinya tindak pidana korupsi di Kota Palopo.

b. Pendapat hukum dalam tahap perencanaan, pelelangan, pelaksanaan, pengawasan pelaksanaan pekerjaan dalam pengadaan barang dan jasa, baik atas inisiatif TP4D maupun atas permintaan instansi dan pihak-pihak yang memerlukan. Tugas TP4D dalam memberikan pendapat hukum dimaksudkan agar tahap perencanaan, pelelangan, pelaksanaan, pengawasan pelaksanaan pekerjaan dalam pengadaan barang dan jasa, baik atas inisiatif TP4D maupun atas permintaan instansi dan pihakpihak yang memerlukan dapat terlaksana dengan baik. 
3. Melakukan koordinasi dengan APIP untuk mencegah terjadinya penyimpangan yang berpotensi menghambat, menggagalkan dan menimbulkan kerugian bagi keuangan negara.

TP4D dalam melakukan koordinasi dengan Aparat Pengawas Internal Pemerintah (APIP) dimaksudkan untuk mencegah terjadinya penyimpangan yang dapat berpotensi menghambat, menggagalkan dan menimbulkan kerugian bagi keuangan negara. Oleh karena itu, tugas TP4D tersebut harus dimaksimalkan guna meminimalisir tindak pidana korupsi di Kota Palopo.

4. Bersama-sama melakukan monitoring dan evaluasi pelaksanaan pekerjaan dan program pembangunan.

Tugas TP4D mengajak masyarakat dan pemerintah untuk bersamasama melakukan monitoring dan evaluasi pelaksanaan pekerjaan dan program pembangunan agar terlaksana secara efektif. Dengan demikian, penyimpangan dan penyalahgunaan anggaran dapat dihindari sehingga mencegah terjadinya tindak pidana korupsi di Kota Palopo.

5. Melaksanakan penegakan hukum represif ketika ditemukan bukti permulaan yang cukup setelah dilakukan koordinasi dengan Aparat Pengawas Internal Pemerintah tentang telah terjadinya perbuatan melawan hukum, penyalahgunaan kewenangan dan atau perbuatan lainnya yang berakibat menimbulkan kerugian keuangan negara.

Tugas TP4D dalam melaksanakan penegakan hukum represif dimaksudkan menemukan bukti permulaan yang cukup setelah dilakukan koordinasi dengan Aapatar Pengawas Internal Pemerintah tentang telah terjadinya perbuatan melawan hukum, penyalahgunaan kewenangan dan atau perbuatan lainnya yang berakibat menimbulkan kerugian keuangan negara. Dengan demikian, tindak pidana korupsi dapat diberantas dan diminimalisir perkembangannya baik kualitas maupun kuantitasnya. 


\section{FAKTOR-FAKTOR YANG MEMPENGARUHI PELAKSANAAN TP4D KEJARI PALOPO DALAM PENCEGAHAN TINDAK PIDANA KORUPSI}

Faktor-faktor yang mempengaruhi pelaksanaan tugas TP4D Kejari Palopo dalam pencegahan tindak pidana korupsi, antara lain: substansi hukum, struktur hukum, budaya hukum, sarana dan prasarana, dan faktor masyarakat. Adapun pengaruh substansi hukum, struktur hukum, budaya hukum, sarana dan prasarana, dan faktor masyarakat terhadap pelaksanaan tugas TP4D Kejari Palopo dalam pencegahan tindak pidana korupsi, akan diuraikan berikut ini.

\section{Susbtansi hukum}

Substansi hukum termasuk sumber daya peraturan perundangundangan sangat menentukan pelaksanaan tugas TP4D Kejari Palopo dalam pencegahan tindak pidana korupsi. Peraturan perundang-undangan dalam hal ini adalah wujud dari ketentuan dalam undang-undang yang berkaitan dengan tindak pidana korupsi. Apabila ketentuan dalam undang-undang tindak pidana korupsi kurang sempurna, maka hal itu tentu berpengaruh terhadap pelaksanaan tugas TP4D Kejari Palopo dalam pencegahan tindak pidana korupsi.

Wewenang Jaksa dalam tindak pidana korupsi diatur dalam Pasal 30 Undang-Undang No. 16 Tahun 2004 tentang Kejaksaan Republik Indonesia menyatakan bahwa: "Salah satu tugas dan kewenangan Kejaksaan di bidang pidana adalah melakukan penyidikan terhadap tindak pidana tertentu berdasarkan undang-undang”.

Dasar Hukum dibentuknya Tim Pengawal dan Pengaman Pemerintahan yaitu Instruksi Presiden Nomor 7 Tahun 2015 tentang Aksi Pencegahan dan Pemberantasan Korupsi Tahun 2015 antara lain dimaksudkan untuk meningkatkan upaya pencegahan terjadinya tindak pidana korupsi di instansi pemerintahan yang perlu didukung dan dilaksanakan secara terncana dan sungguh-sungguh sehingga kegiatan pencegahan korupsi yang dilakukan kejaksaan RI dapat berlangsung efektif dan optimal. Kemudian Instruksi Presiden Nomor 7 tahun 2015 menjadi dasar pertimbangan dikeluarkannya Keputusan Jaksa Agung Republik Indonesia Nomor: KEP-152/A/JA/10/2015 tanggal 1 Oktober 2015 tentang Pembentukan Tim Pengawal dan Pengaman Pemerintahan dan Pembangunan Kejaksaan 
Republik Indonesia kemudian ditindak lanjutkan dengan dikeluarkannya Instruksi Jaksa Agung Republik Indonesia Nomor: INS-001/A/JA/10/2015 tanggal 5 Oktober 2015 tentang Pembentukan Tim Pengawal dan Pengaman Pemerintahan dan Pembangunan pusat dan daerah Kejaksaan Republik Indonesia, termasuk TP4 Daerah yang berkedudukan di Kejaksaan Negeri kususnya Kejaksaan Negeri Palopo menindaklanjuti dengan mengeluarkan Keputusan Kepala Kejaksaan Negeri Palopo Nomor: KEP-06/R.4,13/Dps/11/2015 tanggal 15 Nopember 2015 tentang Pembentukan Tim Pengawal dan Pengaman Pemerintahan dan Pembangunan Daerah (TP4D) Kejaksaan Negeri Palopo

\section{Struktur Hukum}

Struktur hukum merupakan sumber daya penegak hukum khsusnya para jaksa yang tergabung dalam TP4D Kejari Palopo mempersiapkan pengetahuan, keahlian, keterampilan dan keprofesional untuk mengefektifkan pelaksanaan tugas dan fungsi TP4D Kejari Palopo dalam pencegahan tindak pidana korupsi.

TP4D Kejari Palopo bersama konsultan pengawas, Pejabat Pembuat Komitmen untuk melakukan pengawasan dan monitoring kepada pelaksanaan pekerjaan yang dilaksanakan pelaksana kegiatan (kontraktor) untuk menghindari adanya penyimpangan dalam pelaksanaan kegiatan tersebut.

\section{Budaya hukum}

Faktor budaya dapat mempengaruhi sikap, cara berfikir dan cara bertindak yang mengarah pada perbuatan negatif atau positif. Faktor budaya seperti tabiat kurang baik, untuk merubah pola pikir masyarakat dengan cara melakukan penyuluhan dan penerangan hukum kepada masyarakat, pejabat pemerintahan dan pengusaha untuk merubah ciri khas atau kebiasaan yang selalu melanggar aturan dianggap hal yang biasa untuk merubah kebiasaan tersebut menjadikan aturan sesuatu pedoman yang harus ditaati. baik pangkat/jabatan yang tinggi atau rendah serta Pemberian keteladanan yang baik dari pejabat/atasan dalam pelaksanaan tugas, fungsi dan kewenangan yang sesuai dengan peraturan perundang-undangan yang berlaku, namun tetap bijaksana sepanjang masih memiliki batas toleransi. Oleh karena itu, budaya hukum sangat menentukan pelaksanaan tugas TP4D Kejari Palopo dalam pencegahan tindak pidana korupsi. 


\section{Sarana dan prasarana}

Sarana dan prasarana hukum meliputi sumber daya manusia yang dapat mempengaruhi pelaksanaan tugas TP4D Kejari Palopo dalam pencegahan tindak pidana korupsi. Faktor sarana dan prasarana yang mendukung penegakan hukum antara lain: ketersediaan fasilitas kendaraan untuk melakukan peninjauan dilapangan pekerjaan pelaksana sehingga dapat berjalan dengan baik.

\section{PENUTUP}

\section{KESIMPULAN}

Berdasakan hasil penelitian pada bagian terdahulu, maka dapat disimpulkan sebagai berikut :

1. Pelaksanaan tugas TP4D Kejari Palopo dalam pencegahan tindak pidana korupsi telah terlaksana secara efektif, termasuk: melakukan pengawalan dan pengamanan jalannya pemerintahan dan pembangunan melalui upaya-upaya preventif; memberikan pendampingan hokum dalam setiap tahapan program pembangunan; melakukan koordinasi dengan Aparat Pengawasan Internal Pemerintah (APIP) untuk mencegah terjadinya penyimpangan; melakukan monitoring dan evaluasi pelaksanaan pekerjaan dan program pembangunan; dan tugas melaksanakan penegakan hukum represif ketika ditemukan bukti permulaan yang cukup yangmana pelaksanaan TP4D Kejari Palopo ini sebagaimana diamanatkan dalam :

a. Instruksi Presiden Nomor 7 tahun 2015 tentang Aksi Pencegahan dan Pemberantasan Korupsi

b. Keputusan Jaksa Agung RI Nomor : KEP-152/A/JA/10/2015 tanggal 1 Oktober 2015 tentang Pembentukan Tim Pengawal dan Pengamanan Pemerintah dan Pembangunan Kejaksaan RI

c. Instruksi Jaksa Agung Nomor : INS-001/A/JA/10/2015 tanggal 5 Oktober 2015 tentang Pembentukan dan Pelaksaan Tugas Tim Pengawal dan Pengawal Pemerintah dan Pembangunan Pusat dan Daerah Kejaksaan RI 
d. Keputusan Kepala Kejaksaan Negeri Palopo Nomor : KEP06/R.4.13/Dek/11/2015 tentang Pembentukan Tim Pengawal Pengamanan Pemerintahan dan Pembangunan Daerah (TP4D) Kepala Kejaksaan Negeri Palopo tanggal 15 November 2015

2. Faktor - faktor pendukung efektifnya pelaksanaan pengawalan, Pengamanan tugas TP4D Kejari Palopo yaitu :

a. Penerapan substansi hukum yang mengatur tentang kebijakan TP4D telah dilaksanakan sesuai dengan ketentuan dan pelaksanaannya.

b. Para jaksa yang tergabung dalam TP4D Kejari Palopo telah melaksanakan tugas dan fungsinya secara efektif.

c. LSM dan tokoh masyarakat kota Palopo sangat mendukung keberadaan TP4D Kejari Palopo di kota Palopo.

d. Sarana dan prasarana termasud didalamnya, Anggaran tersebut yang dianggarkan oleh pemerintah guna mendukung keberhasilan tugas dan fungsi TP4D kejari palopo .

\section{SARAN}

Berdasarkan pada simpulan sebagaimana yang telah diuraikan di atas, saran yang dapat diberikan adalah sebagai berikut:

1. Perlu mengefektifkan pelaksanaan tugas TP4D Kejari Palopo dalam pencegahan tindak pidana korupsi dengan melakukan pengawalan dan pengamanan jalannya pemerintahan dan pembangunan secara lebih maksimal sehingga dapat lebih efektif lagi,

a. Memberikan pengawalan dan pendampingan hukum dalam setiap tahapan program pembangunan dengan maksimal

b. Melakukan koordinasi dengan APIP ( Aparat Pengawasan Internal Pemerintah ) dengan efektif.

c. Melakukan monitoring dan evaluasi bersama Pejabat pembuat komitmen dan konsultan pengawas secara efektif.

d. Melaksanakan penegakan hukum secara represif dengan cara pencegahan terjadinya tindak pidana korupsi. 
2. Faktor pendukung pelaksanaan TP4D Kejari Palopo meliputi :

a. Substansi hukum terus dipertahankan pelaksanaannya oleh para Jaksa yang tergabung dalam TP4D di Kejari Palopo

b. Struktur hukum penegak hukum khususnya berupa para Jaksa yang tergabung dalam TP4D dapat lebih aktif peranannya dalam pelaksanaan tugas dan fungsi TP4D kejari palopo.

c. Lebih sering melakukan penyuluhan dan peneangan hukum kepada masyarakat sehingga masyarakat dapat turut serta dalam pengawasan pembaguanan bersama TP4D di Kejari Palopo.

d. Ketersediaan anggaran dari pemerintah dalam pelaksanaar dan fungsi TP4D di Kejari Palopo harus lebih di tingkatkan.

\section{DAFTAR PUSTAKA}

\section{Buku Teks:}

Achmad Ali, 2009, Menguak Teori Hukum (Legal Theory) dan Teori Peradilan (Judicialprudence) Termasuk Interpretasi Undang-Undang (Legisprudence), Kencana, Jakarta.

Adami Chazawi, 2002. Pelajaran Hukum Pidana I Bagian I. Raja Grafindo Persada, Jakarta.

Andi Hamzah, 2001. Delik-Delik Tersebar di Luar KUHP dengan Komentar, Pradnya Paramita, Jakarta. , 2004. Pengantar Hukum Pidana, Ghalia, Jakarta. , 2005. Perbandingan Pemberantasan Korupsi di berbagai Negara, Sinar Grafika, Jakarta. , 2007. Pemberantasan Korupsi Melalui Hukum Pidana Nasional dan Internasional, Radja Grafindo Persada, Jakarta.

Andi Zainal Abidin Farid, 1981. Asas-Asas Hukum Pidana, Sinar Grafika, Jakarta

Barda Nawawi Arief, 2000. Kebijakan Legislatif dalam Penanggulangan Kejahatan dengan Pidana Penjara, Badan Penerbit Undip, Semarang. 
, 2001. Masalah Penegakkan Hukum Dan Kebijakan Penanggulangan

Kejahatan, Penerbit Citra Aditya Bakti, Bandung.

2003. Kapita Selekta Hukum Pidana, Citra Aditya Bakti, Bandung.

, 2005. Pembaharuan Hukum Pidana dalam Perspektif Kajian

Perbandingan, Citra Aditya Bakti, Bandung.

, 2007. Beberapa Aspek Pengembangan Ilmu Hukum Pidana (menyongsong Generasi Baru Hukum Pidana Indonesia), badan Penerbit Undip, Semarang.

, 2008. Bunga Rampai Kebijakan Hukum Pidana, Perkembangan Penyusunan Konsep KUHP Baru, Kencana, Jakarta.

, 2008, Perbandingan Hukum Pidana, Badan Penerbit Undip, Semarang.

, 2008, Perkembangan Asas-Asas Hukum Pidana Indonesia, Badan Peneerbit Undip. Semarang.

, 2009, Perkembangan Sistem Pemidanaan di Indonesia, Badan Penerbit Undip, Semarang.

Evi Hartanti, 2005. Tindak Pidana Korupsi, Sinar Grafika, Jakarta

Hermien Hadiati Koeswadji, 2005, Korupsi di Indonesia dari Delik Jabatan ke Tindakan Pidana Korupsi, Citra Aditya Bakti, Bandung.

Indrayanto Seno Adji, 2006, Korupsi Kebijakan Aparatur Negara dan Hukum Pidana, Diadit Media, Jakarta.

Laden Marpaung, 2006. Asas-Teori-Praktik Hukum Pidana (cetakan ketiga), Sinar Grafika, Jakarta.

Lamintang, P.A.F, 1997, Dasar-Dasar Hukum Pidana Indonesia. Citra Aditya Bakti, Bandung.

, dan Djisman Samuti, 2000. Hukum Pidana Indonesia. Sinar Baru, Bandung.

Lawrence M. Friedman, 2009. Sistem Hukum: Perspektif Ilmu Sosial. Penerbit Nusamedia, Jakarta.

Lilik Mulyadi, 2008. Bunga Rampai Hukum Pidana Persfektif, Teoritis dan Praktik, Alumni Bandung, Bandung.

Lili Rosjidi, I.B. Wiyasa Putra, 2003, Hukum Sebagai Suatu Sistem, Bandung, Mandar Maju.

Komariah Emong Sapardja, 2002, Ajaran Sifat Melawan Hukum Materiel dalam

Hukum Pidana Indonesia, Alumni, Bandung. 
Martiman Prodjodikoro. 2007. Memahami Dasar-Dasar Hukum Pidana 2, Pradiya Paramita, Jakarta , 2009. Penerapan Pembuktian terbalik dalam Delik Korupsi, Mandar Maju, Bandung.

M. Solly Lubis, 1985, Pemberantasan UUD 1945, Alumni, Bandung.

Moch. Anwar, 2002. Hukum Pidana Bagian Khusus. KUHP Buku II, Alumni, Bandung.

Moeljatno, 2000. Asas-Asas Hukum Pidana, Rineka Cipta, Jakarta.

Muladi, 2000. Kapita Selekta Sistem Peradilan Pidana, Badan Penerbit Undip, Semarang. , 2002. Lembaga Pidana Bersyarat, Alumni, Bandung.

Muladi dan Barda Arief Nawawi, 2002. Bunga Rampai Hukum Pidana, Alumni, Bandung.

Nyoman Serikat Putra Jaya, 2005. Tindak Pidana Korupsi, Kolusi dan Nepotisme di Indonesia, Badan Penerbit Undip, Semarang. , 2008. Beberapa Pemikiran ke Arah Pengembangan Hukum Pidana, Citra Aditya Bakti, Bandung.

R.E. Baringbing, , 2001. Catur Wangsa yang Bebas Kolusi Simpul Mewujudkan Supremasi Hukum, Pusat Kajian Reformasi, Jakarta.

Rober Klitgaard, 2001. Membasmi Korupsi, Yayasan Obor Indonesia, Jakarta. , 2005, Penuntutan Pemberantasan Korupsi dalam Pemerintahan Daerah, Yayasan Obor Indonesia, Jakarta.

Rohim, 2008. Modus Operandi Tindak Pidana Korupsi, Pena Multi Media, Depok.

Romli Atmasasmita, 2004. Sekitar Masalah Korupsi, Aspek Nasional dan Aspek Internasional, Mandar Maju, Bandung. , 2006. Sistem Peradilan Pidana (criminal justice System), Perspektif Eksistensialisme dan Abolisionisme, Penerbit Bina Cipta, Bandung.

Ronny Rahman Nitibaskara, 2005. Tegakkan Hukum Gunakan Hukum, Kompas, Jakarta. 
Satjipto Rahardjo, 2006. Ilmu Hukum, Citra Aditya Bakti, Bandung.

2007. Pendidikan Hukum sebagai Pendidikan Manusia, Genta Publishing, Yogyakarta. , 2008. Hukum dan Perilaku, Kompas, Jakarta.

, 2009. Membangun dan Merombak Hukum Indonesia Sebuah Pendekatan Lintas Disiplin, Yogyakarta, Genta Publishing.

, 2009, Penegakan Hukum, Suatu Tinjauan Sosiologis, Genta Publishing, Yogyakarta.

Schaffmeister, D.et.all, 1995, Hukum Pidana, Yogyakarta, Liberty.

Soerjono Soekanto, \& Mamudji, Sri, 2003, Penelitian Hukum Normatif, Suatu Tinjauan Singkat, Radja Grafindo Persada, Jakarta.

Soedjono Dirdjosisworo, 2003. Penanggulangan Kejahatan (Crime Prevention). Penerbit Alumni, Bandung.

Soejono dan Abdurrahman. 2003. Metode Penelitian Hukum. Rineka Cipta, Jakarta.

Soerjono Soekanto, 1996. Penelitian Hukum Normatif. Rajawali Pers, Jakarta.

Soetiksno, 2002. Filsafat Hukum (Bagian 1), Pradnya Paramita, Jakarta.

Soetiksno, 2003, Filsafat Hukum (Bagian 2), Pradnya Paramita, Jakarta.

Sudarto.2001, Hukum dan Hukum Pidana, Alumni, Bandung.

Tabalujan S., Benny. 2001, Legal Development in Development Countries the Role of Legal Culture" Singapore.

Thomas Barker dan L. Carter, David, 2000. Police Deviance (Penyimpangan Polisi), Pusat Kajian Reformasi, Cipta Manunggal, Jakarta.

Topo Santoso, \& Achjani Zulfa, Eva, 2003. Kriminologi, Radja Grafindo Persada, Jakarta.

Usman Simanjutak, Teknik Penuntutan dan Upaya Hukum, (Bina Cipta, Jakarta, 1994), halaman 95

Wirjono Prdjodikoro, 2008. Tindak-Tindak Pidana tertentu di Indonesia (cetakan kedua, edisi ketiga), Refika Aditama, Bandung. 


\section{Undang-Undang:}

Undang-undang Dasar Negara Republik Indonesia 1945

KUHAP (UU Nomor 8 Tahun 1981

Undang-Undang Nomor 20 Tahun 2001 Tentang Perubahan Atas UndangUndang Nomor 31 Tahun 1999 Tentang Pemberantasan Tindak Pidana Korupsi.

Inpres No. 5 Tahun 2004 tentang Percepatan Pemberantasan Korupsi.

Instruksi Presiden No. 7 Tahun 2015 tentang Aksi Pencegahan dan Pemberantasan Korupsi Tahun 2015.

Keputusan Jaksa Agung Republik Indonesia No. KEP- 152/A/JA/10/2015 tentang Pembentukan Tim Pengawal dan Pengaman Pemerintahan dan Pembangunan Kejaksaan Republik Indonesia.

Keputusan Jaksa Agung Republik Indonesia No. KEP-001/A/JA/10/2015 tentang Pembentukan Dan Pelaksanaan Tugas TP4 Pusat Dan Daerah Kejaksaan Republik Indonesia

Instruksi Jaksa Agung Republik Indonesia No. INS-001/A/JA/10/2015 tentang Pembentukan dan Pelaksanaan Tugas Tim Pengawal dan Pengaman Pemerintahan dan Pembangunan Kejaksaan Republik Indonesia.

Keputusan Kepala Kejaksaan Negeri Palopo No. KEP-06/R.4.13/Dps/11/ 2015 tentang Pembentukan Tim Pengawal Pengamanan Pemerintahan dan Pembangunan Daerah TP4D Kota Palopo. 